social and gender matters does not imply that his theory cannot cope with them.

In conclusion, although this book has not shaken my commitment to Hobbes, it has certainly provoked me into thinking about it - over a glass of real ale, alas.

\title{
References
}

Hobbes, T. (1996) in R. Tuck (ed.) Leviathan, Cambridge: Cambridge University Press.

Tuck, R. (1999) The Rights of War and Peace: Political Thought and International Order from Grotius to Kant, Oxford: Oxford Univerity Press.

\section{States and Citizens: History, Theory, Prospects}

Quentin Skinner and Bo Strath (eds.)

Cambridge University Press, Cambridge, 2003, viii $+326 p p$.

ISBN: 0521539269.

Contemporary Political Theory (2005) 4, 85-87. doi:10.1057/palgrave.cpt.9300159

This volume of essays is based on a conference at the European University Institute in 2000. It provides a remarkably unified perspective on the state; one that stresses the difficulty of defining it, the surprising twists and turns in its development, and the dangers of trying to analyse it in terms of contemporary understandings of law, liberty and rights. After a brief overview of the volume by Strath and Skinner, we have a set of essays by Skinner, David Runciman and Gianfranco Poggi that are supposed to set the scene for subsequent articles on the history of the western state by Magnus Ryan, Almut Hofert, Martin van Gelederen and Annabel Brett and then on citizens, states, modernity and postmodernity by Judith Vega, Lucien Jaume, Sudipta Kaviraj, Bo Strath, Michele Riot Sarcey and Andrew Dobson. I must admit, however, to some uncertainties about the target audience for this book. It seems too historical and too uninterested in normative questions to be of much interest to political and social theorists. Despite a chapter on post-colonial India, it is too interested in the Western experience (primarily, it must be said, France, England, Germany and the Netherlands) to be of interest to people in non-European politics. Also, despite a nod to problems in the representation of women, and to environmental issues, it seems to depend on a rather abstract picture of state-citizen relations, in which 
the role of intermediate groups within the state, or conflicts between state and nation have no role. For these reasons, I am sceptical that political scientists will find this volume particularly useful either. That said, it should be of considerable interest to historians, and to those who would like to catch up on the latest developments in the historiography of the medieval and modern state.

The strengths and weaknesses of the volume can be illustrated by Skinner's article on states and the freedom of citizens. In essence this is a careful, and illuminating, case study of changing uses of the language of liberty in England from the 17 th to the 19 th century. It traces the challenge to an older idea of liberty as a privilege or immunity - an exemption from otherwise binding laws or norms - to the neo-Roman idea of liberty as independence, or freedom from the arbitrary will of another, through to the Hobbesian idea of liberty as the absence of external impediments to action, and on to Mill's worries about the implications for our freedom of internalized customs and opinions. The earlier part of this story receives the most attention, and Skinner's sketch of the way in which Hobbes' conception of liberty exposed, and capitalized, on the weaknesses in the neo-Roman view is well done. But in his conclusion, Skinner wants to claim that each of these different ways of thinking about liberty is internally coherent, and that while we may wish to dismiss the social philosophies with which they are associated, we cannot usefully ask which of the various theories of liberty is the correct one. However, this claim requires a great deal of argument, not a summary paragraph. After all, it is far from clear that a Hobbesian concern for freedom should lead us to choose absolute monarchy over the alternatives, whatever the problems with that conception of freedom itself. Likewise, Bentham's reasons for thinking that there can be no such thing as a coercive offer (for example, 'have sex with me, and I'll give you the job'), hardly follows from the idea that we need to distinguish among what Locke called 'Sollicitations, Threats, Promises' in order to decide which of these are to count as coercive. Moreover, as Dworkin and Rawls have some claim to providing distinctive pictures of liberty that aim to address the relative strengths and weaknesses of these different interpretations of the concept, there is something bizarre and potentially quite misleading about Skinner's brief skip through Green, Hobhouse, and Berlin to Nozick and Robert Paul Wolff with no mention at all of two of the most influential Anglo-American thinkers on liberty in the post-war period.

Likewise, David Runciman's article on 'The concept of the state: the sovereignty of a fiction' is at once learned and engaging, and deeply frustrating. The main point of the article is to show that while what states do is all too real - taxation, regulation, prosecution, punishment, war — 'it is very hard to find anyone or anything in the real world' with which to identify the state. Thus, we cannot 'simply' identify states with governments, 'because a government is 
always a collection of named individuals, none of whom could ever sustain the fiscal burden of the state's debt, or the moral burden of the state's acts of violence' (p. 28). But this seems rather different from saying that the state 'is never to be identified with anyone or anything, in particular' (p. 37). This is not to deny the force of Runciman's point that it is terribly difficult to provide a phenomenological account of the state - or of money - and that scarcely anyone, anymore, asks questions like 'what is the state?' or 'what is money?' though these were once staples of political and economic thought. The point, rather, is that if such questions are worth trying to answer nowadays we should not expect them to be simple, and should expect them have some bearing on how we think about particular people, events and associations. Hence, Runciman's readiness to dismiss the latter at the outset seems to foreclose, unnecessarily, the most promising means to a better sense of the state as a lived reality, not just a legal fiction. Hence, too, my discomfort with the editorial decision to ignore intermediate associations, and their role in shaping, even constituting, state-citizen relations: this makes the state seem desperately abstract, and to make the fine historical articles in this volume unnecessarily inaccessible to those with more contemporary and theoretical concerns.

Annabelle Lever University College London, UK

\section{Political Concepts}

Richard Bellamy and Andrew Mason (eds.)

Manchester University Press, Manchester, 2003, viii $+245 p p$.

ISBN: 071905908 9/0 719059097.

\section{Political Thinkers: From Socrates to the Present}

David Boucher and Paul Kelly (eds.)

Oxford University Press, Oxford, 2003, xvi $548 p$.

ISBN: 0198781946.

Contemporary Political Theory (2005) 4, 87-90. doi:10.1057/palgrave.cpt.9300152

These are a worthwhile couple of books that a variety of readers are likely to find useful in their different ways. The first, Political Concepts, aims to provide introductory analyses of the political concepts that form the building blocks of political argument. As well as the target audience of textbook buying students, the book is deemed to be perfect 'for anyone approaching political theory for 